\title{
DYOTHELITISME DALAM KRISTOLOGI YOHANES CALVIN
}

\author{
Tonny Sutrisno ${ }^{1}$, Billy Kristanto ${ }^{2}$ \\ 1, 2 Sekolah Tinggi Teologi Reformed Injili Internasional \\ Korespondensi: tonnyrbs@gmail.com, bkrstn@yahoo.com
}

\begin{abstract}
The continuity in the Orthodox understanding of the two wills of Christ, which is based on His two natures (Dyothelitism) is very important in order to understand about the Person of Christ, and how the work of redemption was perfectly performed by Him during His incarnation as the Logos that assumed a human nature. Dyothelitism which was represented by the thought of Maximus the Confessor is a reference in order to understand the Christology of two natures - one Person of Chalcedon, which has been accepted by the Church as an orthodoxy in the fight against Monothelitism and Monoenergism. The continuance between Maximus the Confessor's Dyothelite thoughts and the thoughts and works of John Calvin in his Christology, is very important for the understanding of the implementation and perfect fulfillment of Christ's atoning work in the view of Reformed theology as represented by Calvin.
\end{abstract}

KEYWORDS: Dyothelitisme; Monothelitisme; hypostasis; person; ousia; essence; nature; divinity; humanity

ABSTRAK: Kesinambungan di dalam pemahaman ortodoks mengenai dua kehendak Kristus, berdasarkan dua natur-Nya (Dyothelitisme) merupakan hal yang sangat penting untuk mengerti mengenai Pribadi Kristus dan bagaimana pekerjaan penebusan dilaksanakan dengan sempurna oleh Pribadi-Nya, di dalam inkarnasi Sang Logos yang mengambil natur manusia. Dyothelitisme yang diwakili oleh pemikiran Maximus the Confessor merupakan acuan di dalam memahami Kristologi dua natur - satu pribadi dari Chalcedon, yang diterima sebagai ortodoksi Gereja di dalam melawan ajaran Monothelitisme dan Monoenergisme. Kesinambungan 
antara pemikiran Dyothelitisme Maximus the Confessor tersebut dengan pemikiran serta karya Yohanes Calvin di dalam Kristologinya, adalah sangat penting bagi pemahanan mengenai pelaksanaan dan penggenapan sempurna karya penebusan Kristus di dalam pandangan teologia Reformed sebagaimana diwakili oleh Calvin.

KATA KUNCI: Dyothelitisme; Monothelitisme; hypostasis; pribadi; ousia; essence; natur; ke-ilahian; kemanusiaan

\section{Introduction}

Pengenalan yang benar terhadap doktrin dua-kehendak Kristus (Dyothelitisme) akan memberikan pengertian tentang bagaimana karya keselamatan dijalankan dan digenapi oleh Pribadi Kristus, serta membawa kepada kesadaran akan pentingnya ketaatan kepada kehendak Allah bagi setiap orang percaya. Pribadi Kristus melalui kehendak kemanusiaan-Nya yang tunduk sempurna kepada kehendak Bapa, menjadi syarat mutlak bagi teladan ketaatan yang harus dilakukan oleh setiap orang percaya. Di dalam hal ini, Melchisedec Törönen mencatat tulisan Maximus the Confessor bagaimana kehendak kemanusiaan Kristus tunduk kepada kehendak Bapa:

All that matters is a perfect verification of the will of the Father, in his saying a human being, Not mine, but your will be done, by this giving himself as a type and example of setting aside our own will by the perfect fulfilment of the divine, even if because of this we find ourselves face to face with death. ${ }^{1}$

Maximus the Confessor atau Maximus the Teologian atau Maximus of Constantinople (580 - 13 Agustus 662) adalah seorang biarawan, teolog, dan cendikiawan yang memiliki kontribusi besar di dalam 'Dyothelite Christology'. Ia mempertahankan keyakinannya dan kehilangan kebebasannya, kehilangan tangan kanannya, lidahnya dipotong dan pada akhirnya kehilangan nyawanya. ${ }^{2}$ Maximus menegaskan kembali resolusi dari konsili-konsili di Nicea I (325), Constantinople I (381), Ephesus (431), Chalcedon (451), dan Constantinople II (553), yang pada akhirnya Ecumenical Council of Constantinople III (680) memperkuat resolusi bahwa Yesus Kristus memiliki dua-kehendak, sebagai manusia dan Allah. ${ }^{3}$

1 Melchisedec Törönen, Union and Distinction in the Thought of St Maximus the Confessor, eds. G. Clark and A. Louth (Oxford University Press, Oxford; New York, 2007), 113

2 https://en.wikisource.org/wiki/1911_Encyclopædia_Britannica/Maximus,_St, Accessed January $12^{\text {th }}, 2019$.

3 Jaroslav Pelikan, Valerie Hotchkiss, Creeds ad Confessions of Faith in thre Christian Tradition: Volume One (Yale Univversity Press, New Haven, 2003), 225 
Penekanan doktrinal mengenai kesatuan Kristus, antara Monenergite - Monothelite dan Dyoenergite - Dyothelite, memiliki persamaan di dalam pentingnya kesatuan Pribadi Kristus. Perbedaan keduanya terletak pada pengakuan atas jumlah kehendak dan energi yang dimiliki Kristus. Bagi Monenergite - Monothelite, satu kehendak dan satu energi dianggap sebagai bagian dari pengakuan akan ke-satuan Kristus. Tetapi sebagaimana tercatat dalam 'the encyclical of Sophronius,' Dyonergists - Dyothelite mendasarkan pengakuan imannya pada keberadaan dua kehendak dan dua energi Kristus. ${ }^{4}$ Bagi Maximus kesatuan Kristus (Oneness of Christ) adalah satu pribadi dan dua natur. Dan Maximus juga menekankan bahwa kehendak natur manusia Kristus dijaga terhadap kemungkinan bahwa Ia juga memiliki 'gnomic' (deliberative) will ( $\gamma \nu \omega ́ \mu \eta$ - gnome) dalam watak manusia yang sudah jatuh dalam dosa. ${ }^{5}$ Di dalam pandangan Maximus, 'gnomic will' atau 'deliberative will' tersebut, bukan merupakan bagian dari natur atau esensi. Alasannya adalah karena jika 'gnomic will' merupakan bagian dari natur, maka hal tersebut adalah sama dengan menyatakan bahwa Allah adalah penyebab dosa. Tetapi 'gnomic will' lebih merupakan suatu kualitas atau sebagai suatu cara di dalam menggunakan kehendak menurut apa yang dianggapnya baik, menjadi suatu tindakan yang menyebabkan keberdosaan. ${ }^{6}$

Mengenai asumsi natur manusia dalam inkarnasi Kristus, Gregory Nazianzus melalui aksioma anti-Apollinariannya menyatakan: "what is not assumed is not healed." ${ }^{7}$ Maka penebusan berdasarkan prinsip tersebut adalah natur manusia atau bagian dari natur manusia jika tidak diasumsi oleh Kristus di dalam Inkarnasi-Nya, tidak akan mengalami penebusan. Pencapaian karya penebusan bagi seluruh ciptaan Allah, terjadi di dalam Pribadi Kristus melalui tubuh-Nya yang juga merupakan tubuh dari Sang Firman yang kekal. ${ }^{8}$ Athanasius of Alexandria (296 - 373), menempatkan dirinya sebagai pendukung ke-ilahian penuh Kristus, bertentangan dengan banyak orang pada zamannya. Pendapat Athanasius tentang keselamatan menempatkan Kristus sebagai manusia seutuhnya, karena bukan hanya tubuh saja tetapi Ia juga memiliki roh manusia. ${ }^{9}$

\footnotetext{
4 Cyril Hovorun, Will, Action, and Freedom: Christological Controversies in the Seventh Century, (Brill, Leiden, 2008), 103.

5 Maximus the Confessor, Disputations with Pyrrhus, trans. Joseph P. Farrel (St. Tikhon's Seminary Press, Waymart, Pensylvania, 1990), \#87, 31-32 .

Maximus, Disputations, \#79, \#85, \#8, xxi, 30-31.

Adam G. Cooper, The Body in St Maximus the Confessor: Holy Flesh, Wholly Deified (Oxford, New York: Oxford University Press, 2005), 7.

8 Ibid., 6-7.

9 Charles C. Twombly, "The Nature of Christ's Humanity: A Study In Athanasius," Patristic and Byzantine Review 8, no. 3 (1989), 227.
} 
Salah satu dilema Trinitarian dan Kristologi adalah, jika Bapa adalah Pribadi, Kristus adalah Pribadi, dan Roh Kudus adalah Pribadi, maka bagaimana menjelaskan bahwa hanya ada satu Allah bukan tiga Allah. Kemudian jika Kristus adalah Allah dan juga manusia, bagaimana menjelaskan bahwa Ia adalah satu Pribadi bukan dua pribadi. Arianisme kemudian datang dengan pemikiran bahwa terdapat tiga 'essences' (esensi) berbeda, dan akibatnya, menyamakan 'hypostasis' dengan 'essence,' sehingga jatuh kepada pemahaman bahwa tiga 'hypostases' sama dengan tiga 'essences'. ${ }^{10}$ Sehingga membedakan antara essence dan hypostasis merupakan satu-satunya jalan keluar. Gregory of Nyssa, sebagaimana dituliskan Törönen, secara kontras menyatakan bahwa:

the Scripture ... safeguards the identity of the godhead in the particularity of the three hypostases, that is to say, persons $(\pi \varrho o ́ \sigma \omega \pi \alpha)$. When we say particular

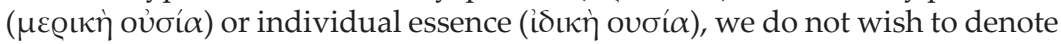

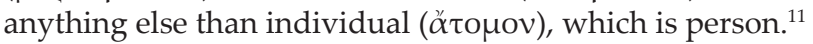

Maka bagi Gregory of Nyssa terdapat tiga gagasan: hypostasis, person, dan individu yang identik, dan identifikasi ini kemudian menjadi standar dalam tradisi teologi Chalcedon.

Maximus sangat berhati-hati untuk tidak keluar dari kerangka teologis Chalcedon dan melanggar batasan-batasan pemahaman Trinitas. Törönen menuliskan bahwa Maximus menyimpulkan peristilahan ini dengan satu kalimat:

Common and universal, that is to say generic, is, according to the Fathers, the essence and nature, for they say that these two are identical with each other. Individual and particular is the hypostasis and person, for these too are identical with each other. ${ }^{12}$

Bagi Maximus ini adalah tradisi para bapa Gereja, yang baginya merupakan prinsip atau aturan. Kekacauan dalam mengerti prinsip ini akan membawa kepada permasalahan doktrinal. Menurut Tollefsen, dasar sistem pengakuan Maximus adalah pengakuan mengenai Tritunggal dan inkarnasi Sang Anak Allah dari Konsili Chalcedon (451): natur yang tidak diciptakan dan natur yang diciptakan di dalam Kristus yang dipersatukan tanpa pencampuran, tanpa perubahan, tanpa pembagian, tanpa pemisahan dalam hypostasis Sang Logos. Logika ini menurut Maximus, bukan hanya mengatur terutama inkarnasi sang Logos, tetapi juga hukum umum bagi

\footnotetext{
Törönen, Union and Distinction, 47-50.

11 Ibid., 50.

2 Ibid., 52.
} 
relasi antara ranah Pencipta dan ciptaan. ${ }^{13}$

Konsili Chalcedon (451) mendeklarasikan satu hypostasis dengan dua natur yang tidak terpisah dan tidak bercampur (ilahi dan manusia) di dalam Kristus. ${ }^{14}$ Rumusan Kristologi Dyophysite Chalcedon ini menjadi dasar ortodoksi Gereja Timur dan Barat. Gereja Ortodoks Oriental adalah salah satu Gereja non-Chalcedonian yang cenderung mengarah kepada Monophysitism (satu natur), dan mengadopsi pandangan Miaphysite (dua natur menjadi satu natur baru). Konsili Chalcedon dianggap telah meletakkan dasar yang benar bagi permasalahan Kristologis, namun membuka paradigma baru di dalam memahami pribadi dan natur Kristus dengan lebih tepat. Basil Studer menyatakan:

The faith of Chalcedon must in fact be regarded not only as the final point of a long development, but also as the starting point for fresh Christological discussions. ${ }^{15}$

Kemudian pada konsili Constantinople II (553) dinyatakan secara tegas bahwa satu Pribadi (hypostasis) dari Tuhan Yesus Kristus adalah sang Firman Ilahi: "We confess therefore, there is but one hypostasis or person our Lord Jesus Christ." 16

Kontroversi Monothelite (satu kehendak) muncul pada abad ke-tujuh sebagai bentuk penolakan atas hasil konsili Chalcedon (451) yang secara implisit menerima Dyothelitisme. Mengenai hasil konsili Chalcedon (451), Neuner dan Dupuis menuliskan:

We confess that the one and the same Lord Jesus Christ, the only-begotten Son, must be acknowledged in two natures, without confusion or change, without division or separation. The distinction between the natures was never abolished by their union but rather the character proper to each of the two natures was preserved as they came together in one person and one hypostasis. He is not split or divided into two persons, but he is one and the same Only-begotten, God the Word, the Lord Jesus Christ. ${ }^{17}$

Perdebatan Dyothelite dan Monothelite dalam banyak hal terbungkus dalam perselisihan antara Maximus the Confessor, lawan utama dari Monothelitisme, dan Pyrrhus yang mendukung Monothelitisme. Pyrrhus berpendapat Kristus memiliki satu kehendak dan satu energi, karena Ia

13 Torstein Theodor Tollefsen, The Christocentric Cosmology of St Maximus the Confessor, ed. G. Clark \& A. Louth (Oxford University Press, Oxford, 2008), 10.

14 John J. Duffy, John Parker, Synodicon Vetus (Dumbartons Oaks Publication, Washington, 1979), 81.

15 Basil Studer, Andrew Louth, Trinity and Incarnation: The Faith of the Early Church (Liturgical Press, Collegeville, Minnesota, 1993), 218.

16 Joseph Neuner, Jacques Dupuis, The Christian Faith in the Doctrinal Documents of the Catholic Church, $7^{\text {th }}$ ed. (Alba House, New York, 2001), 233.

17 Ibid., 228. 
adalah satu Pribadi sehingga berkehendak dan bertindak sebagai satu Pribadi. ${ }^{18}$ Bagi Pyrrhus, kehendak adalah milik pribadi. Sehingga dalam logika Chalcedon: Kristus hanya dapat memiliki satu kehendak yang berhubungan dengan pribadi-Nya yang satu. Maximus berpendapat bahwa kehendak adalah milik dari natur. Sehingga berdasarkan logika Chalcedon: Kristus memiliki dua-kehendak, kehendak ilahi dan kehendak manusia, yang berhubungan dengan dua natur-Nya. Bagi Maximus, posisi dua-kehendak Kristus adalah yang diharuskan bagi karya Kristus sebagai Mediator antara Allah dan manusia. Ia menjelaskan bahwa Dyothelitisme menjamin kesanggupan Kristus, sebagai Allah dan manusia, untuk menggenapkan karya penebusan:

This is why, considering both of the natures from which, in which, and of which His person was, is acknowledged as able both to will and to affect our salvation. ${ }^{19}$

Pribadi Kristus menurut natur/kehendak keilahian-Nya dapat menyelamatkan dan menurut natur/kehendak manusia-Nya dapat taat kepada Bapa. Melalui pemahaman Dyothelitenya, Maximus menawarkan pemahaman yang penting secara teologis tentang peran kehendak natur manusia Kristus dan peran ketaatan Pribadi-Nya di dalam natur manusia, bagi penggenapan seluruh karya keselamatan. ${ }^{20}$ Dyothelitisme pada akhirnya diterima pada Konsili Ekumenikal Constantinople III (680-81), dan Monothelitisme dinyatakan ditolak. ${ }^{21}$

Thomas Aquinas (1225 - 1274) salah seorang teolog berpengaruh lewat karya-karyanya pada masa 'High Middle Ages', secara langsung bergantung kepada Yohanes dari Damascus di dalam mempertahankan Dyothelitismenya. ${ }^{22}$ Bagi Aquinas, natur manusia Kristus memiliki kehendak-Nya sendiri, sebagaimana ia nyatakan dalam responsnya terhadap Monothelitisme:

Hence we must say that the Son of God assumed a human will, together with human nature. Now by the assumption of human nature the Son of God suffered no diminution of what pertains to His Divine Nature, to which it belongs to have a will, as was said in the FP, Q [19], A[1]. Hence it must be said that there are two wills in Christ, i.e. one human, the other Divine. ${ }^{23}$

\footnotetext{
18 Demetrios Bathrellos, The Byzantine Christ: Person, Nature, and Will in the Christology of Saint Maximus the Confessor, ed. G. Clark \& A. Louth (Oxforf University Press, 2004), 94-95.

19 Maximus the Confessor, On the Cosmic Mystery of Jesus Christ, trans. Paul M. Blowers and Robert Louis Wilken (St. Vladimir Press, New York, 2003) 177.

20 Bathrellos, The Byzantine Christ, 56.

21 Hovorun, Will, Action and Freedom, 145.

22 Joseph P. Wawrykow, The Westminster Handbook to Thomas Aquinas (Westmisnter John Knox, Louisville, 2005), 15-125.

23 Thomas Aquinas, Summa Teologica, trans. Fathers of the English Dominican Province (Encyclopedia
} 
Aquinas membuktikan bahwa pandangan dua-kehendak dari Constantinople III secara logis mengikuti pandangan dua-natur Chalcedon. Kristus mengambil natur manusia secara sempurna, dimana Chalcedon menjelaskan dengan istilah tubuh dan roh rasional. Aquinas berpendapat bahwa kehendak dan intelektualitas adalah bagian yang layak dari natur manusia. Maka ketika Kristus mengambil natur manusia, Ia juga mengambil kehendak manusia.

Gereja-gereja Barat memegang Dyothelitisme sebagaimana diposisikan oleh Thomas Aquinas, yang setuju dengan pernyataan Maximus:

The power of the will is natural, and necessarily follows upon the nature. hence besides the Divine will it is necessary to place in Christ a human will. ${ }^{24}$

Pemahaman Aquinas serupa dengan Maximus bahwa kehendak dimiliki oleh natur, bukan pribadi; sehingga Kristus dengan dua natur-Nya harus memiliki dua-kehendak. Para teolog zaman Medieval menerima hasil konsili Constantinople III sebagai hal yang otoritatif. Para reformator Protestan lebih banyak berkonsentrasi pada permasalahan Gereja dalam hal Soteriologis dan Eklesiologis dari zaman abad pertengahan akhir, sehingga masalah di dalam pemahaman Trinitas dan Kristologis relatif tidak banyak tersentuh. ${ }^{25}$ Reformasi terkonsentrasi pada Alkitab, Pembenaran, dan natur dari Gereja yang sejati, tidak pada Trinitas atau pribadi Kristus.

\section{Dyothelitisme di dalam peran Kristus sebagai Mediator menurut Kristologi Yohanes Calvin}

Yohanes Calvin (1509 - 1564) menyatakan dukungannya terhadap Dyothelitisme melalui karya penafsiran (commentary) dan Institutes of Christian Religion. Terutama di dalam penafsirannya mengenai Pribadi dan natur Kristus sebagai Sang Mediator. Calvin tidak mewariskan suatu karya tulis khusus dalam Kristologi, tetapi karakter Kristosentrik sangat nyata dalam karya-karyanya. ${ }^{26}$ Bagi Calvin sangatlah penting untuk memahami Alkitab sebagai suatu kesaksian tentang Kristus dan karya-Nya. Bagi Calvin, seluruh Injil terkandung di dalam Pribadi Kristus, di dalam penafsirannya atas Roma 1:3, ia menyatakan bahwa:

\footnotetext{
Britanica, Chicago, 1952), 3.18.1.

24 Aquinas, Summa Teologica, 3.18.1

25 https://anglicancontinuum.blogspot.com/2011/07/christology-and-soteriology.html Accessed January $21^{\text {st }}, 2019$.

26 Francois Wendel, Calvin: The Origins and Development of his Religious Thought, trans. Philip Mairet (Harper Collins, London, 1963), 215.
} 
To move even a step from Christ means to withdraw oneself from the Gospel. Since Christ is the living and express image of the Father, it need not surprise us that He alone is set in front of us as the One who is both the object and centre of our whole faith. ${ }^{27}$

Sebagaimana Maximus, Calvin memahami keberadaan dua natur berbeda yang masing-masing mempertahankan sifat-sifatnya di dalam satu Pribadi Kristus:

For we affirm his divinity so joined and united with his humanity that each retains its distinctive nature unimpaired, and yet these two natures constitute one Christ. ${ }^{28}$

Calvin juga menekankan peran Kristus yang berinkarnasi menjadi manusia untuk menggenapi peran-Nya sebagai Mediator. Di dalam inkarnasi-Nya, Kristus adalah Allah sejati dan manusia sejati, sebagai satu-satunya Pribadi yang dapat memediasi Allah dan manusia berdosa. Hal tersebut dikemukakan Calvin di dalam Institutes:

Ungrudgingly he took our nature upon himself to impart to us what was his, and to become both Son of God and Son of man in common with us. Hence that holy brotherhood which he commends with his own lips when he says: "I am ascending to my Father and your Father, to my God and your God [John 20:17]. In this way we are assured of the inheritance of the Heavenly Kingdom; for the only Son of God, to whom it wholly belongs, has adopted us as his brothers. "For if brothers, then also fellow heirs with him." [Rom. 8:17 p.]. ${ }^{29}$

Selanjutnya Calvin berpendapat bahwa hanya Dia yang sungguh-sungguh benar yang dapat berlaku sebagai Mediator. Hanya Allah yang dapat melakukannya dengan mengirimkan Anak-Nya yang tunggal sebagai Penebus. ${ }^{30}$ Sebagaimana yang dinyatakan Alkitab bahwa setiap karya Kristus adalah karya Pribadi-Nya, maka Calvin juga berpendapat bahwa karya mediasi adalah karya inkarnasi Kristus, dan bukan merupakan karya kedua natur-Nya, akan tetapi merupakan karya Pribadi Kristus yang dilakukan melalui kedua natur-Nya. ${ }^{31}$ Bagi Calvin ke-ilahian Kristus sama krusialnya dengan kemanusiaan-Nya di dalam karya mediasi:

To unite us to God and to be one with God? Without doubt, these will not be found in Christ's human nature apart from the divinity, yet they do come into

27 John Calvin, The Epistles of Paul to the Romans and Thessalonians, trans. by R. Mackenzie; ed. by D. W. Torrance \& T. F. Torrance; Calvin's New Testament Commentaries 8 (Eerdmans, Grand Rapids, 1973), 15 .

28 John Calvin, Institutes of the Christian Religion, ed. John T. McNeill, trans. And idexed by Ford Lewis Battles (John Knox Press, Louisville, London), 2.14.1.

29 Ibid., 2.12.2.

30 Ibid., 2.12.2.

31 Stephen Edmonson, Calvin's Christology (Cambridge University Press, Cambridge, 2004), 31. 
consideration when it is a question of the Mediator's office. ${ }^{32}$

Pandangan Kristologis konservatif Calvin juga tergambar pada penafsirannya atas perkataan Tuhan Yesus di taman Getsemani dalam Lukas 22:42:

This passage shows plainly enough the gross folly of those ancient heretics, who were called Monothelites, because they imagined that the will of Christ was but one and simple; for Christ, as he was God, willed nothing different from the Father; and therefore, it follows, that his human soul had affections distinct from the secret purpose of God. ${ }^{33}$

Melalui penafsiran bahwa kehendak natur ilahi Kristus adalah sama dengan kehendak Bapa, maka Calvin juga sedang menyatakan kesenaturan (homoousios) antara natur ilahi Kristus dengan natur Bapa. Di dalam penafsirannya atas Filipi 2:6, Calvin menegaskan kesenaturan Sang Anak Allah yang setara dengan Bapa:

For in the wisdom of God, prior to his assuming our flesh, there was nothing mean or contemptible, but on the contrary a magnificence worth of God. Being such as he was, he could, without doing wrong to any one, shew himself equal with $\operatorname{God}^{34}$

Maka pemahaman Calvin tersebut adalah sesuai dengan Dyothelitisme yang menempatkan kehendak di dalam natur. Penafsiran Calvin akan narasi Getsemani menunjukkan pemahaman Calvin bahwa Kristus mengambil kehendak yang berbeda dengan apa yang Ia miliki secara kekal dengan Bapa, sebuah kehendak manusia sebagai bagian dari roh manusia-Nya. Mengenai peran kehendak natur manusia Kristus di dalam karya keselamatan, Calvin menyatakan:

As if he could atone for our sins in any other way than by obeying the Father! But where is inclination or will to obey except in the soul? We know that it was for this reason that his soul was troubled: to drive away fear and bring peace and repose to our souls. ${ }^{35}$

Pemahaman Calvin tersebut juga merupakan bukti dukungannya terhadap natur manusia Kristus yang konkret, sebagaimana pemahaman Maximus. Karena hanya natur manusia konkret yang memiliki kehendak

32 Ibid., 32.

33 John Calvin, A Commentary on A Harmony of the Evangelists: Matthew, Mark, and Luke, trans. William Pringle, Calvin's Commentaries (Baker Books, Grand Rapids, 2003), 3:233.

34 John Calvin, Commentary on the Epistle of Paul to the Philippians in Commentaries on the Epistles of Paul the Apostle to the Philippians, Colossians, and Thessalonians, trans. William Pringle, Calvin's Commentaries (Baker Books, Grand Rapids, 2003), 55.

35 Calvin, Institutes, 2.16.12; pada bagian ini pula Calvin menyebut pandangan monothelitisme bersama Apollinarisme sebagai pandangan yang salah 
melalui keberadaan roh rasionalnya. Maka dengan demikian tradisi teologia Reformed yang dibangun Calvin jelas menegaskan doktrin ortodoks mengenai dua-kehendak Kristus. ${ }^{36}$

\section{Dyothelitisme melalui Pemakaian istilah Pribadi, Natur, dan Natur Konkret di dalam Kristologi Yohanes Calvin}

Salah satu hal yang sangat penting secara teologis dan historis adalah penggunaan istilah atau terminologi yang dikemukakan oleh 'the Cappadocians Fathers' di dalam konsili Nicea I (325) mengenai perbedaan "ousia dan hypostasis" (natur/essence dan pribadi/person/subsistence), yang kemudian membantu memperjelas posisi Kristologi Chalcedon, sehingga menolong integrasi teologi dan karya Allah, ke dalam Kristologi, serta memperlengkapi Gereja agar dapat menjaga iman dari penyimpangan Nestorianisme dan Monophysitisme. ${ }^{37}$ Dalam Kristologinya, Calvin mendukung pemahaman Chalcedon tersebut. Hal tersebut nampak dalam penggunaan istilah 'person' (pribadi) dalam pemahamannya terhadap Trinitas, sebagai suatu bentuk keberadaan ketiga Pribadi Allah. ${ }^{38}$

Ketika Calvin berbicara tentang 'pribadi Kristus', ia berbicara tentang posisi Kristus sebagi Perantara antara Allah dan manusia, yang merupakan subordinat Bapa dalam misi penebusan. Calvin menggunakan kata 'person' (pribadi) yang disebutnya sebagai 'subsistence,' sebagai yang berbeda dengan 'essence'. Mengacu kepada pengertian tersebut maka istilah Pribadi Kristus bagi Calvin menunjuk kepada Pribadi Sang Allah Anak yang menghidupkan kedua natur Kristus. Bagi Calvin, keberadaan ketiga Pribadi Allah yang memiliki 'essence' (esensi/natur) yang sama, tidak berpengaruh terhadap ketunggalan esensi atau natur Allah. ${ }^{39}$ Calvin menggunakan istilah 'person' (pribadi) dalam beberapa cara, dan seringkali mengacu kepada suatu peran individu. ${ }^{40}$ Sehingga penggunaan istilah 'pribadi' dan 'natur' dalam Kristologi Calvin adalah juga mengacu kepada pengertian Dyothelitisme. Ketika berbicara mengenai natur manusia Kristus, Calvin menyatakan:

that in Christ two natures are in such a manner distinguished, that they are at the same time united in the very person of Christ: for by saying that Christ had descended from the Jews, he declared his real humanity. ${ }^{41}$

\footnotetext{
Charles Hodge, Systematic Theoology (Eerdmans, Grand Rapids, 1970), 2:404-5.

Bathrellos, The Byzantine Christ, 29.

Calvin, Institutes, 1.13.6.

Ibid., 1.13.6.

Edmondson, Calvin's Christology, 192.

John Calvin, Commentaries on the Epistles of Paul the Apostle to the Romans, trans. And ed. By the Rev. John Owen (Baker book house, Grand Rapids, Michigan, 2005), 342.
} 
Sedangkan mengenai natur ilahi Kristus, Calvin bukan saja menyatakan bahwa Kristus memiliki natur yang sama dengan Allah, tetapi juga Ia adalah gambaran Allah (image of God) yang di dalam Inkarnasi-Nya membuat Allah dapat dilihat oleh manusia. ${ }^{42}$ Dan pada bagian lain, di dalam penafsiran Calvin terhadap surat Kolose, ia menyatakan:

Further, when he says that the fullness of the Godhead dwells in Christ, he means simply, that God is wholly found in him, so that he who is not contented with Christ alone, desires something better and more excellent than God. The sum is this, that God has manifested himself to us fully and perfectly in Christ. ${ }^{43}$

Maka bagi Calvin, keberadaan kedua natur (ilahi dan manusia) secara sempurna di dalam Pribadi Kristus tidak pernah merupakan hal yang saling berbenturan atau berlawanan sehingga kesempurnaan salah satu natur harus dikorbankan demi tercapainya kesatuan Pribadi Kristus.

Bagi Calvin, dua kehendak di dalam Pribadi Kristus merupakan suatu kesatuan, selayaknya musik yang memiliki nada dan harmoni, dan ia menegaskan bahwa:

so in Christ there was a remarkable example of adaptation between the two wills, in the will of God and the will of man, so that they differed from each other without any conflict or opposition. ${ }^{44}$

Calvin juga menerapkan konsep Dyothelite di dalam penafsirannya terhadap doa Tuhan Yesus di taman Getsemani, sebagai suatu contoh bagaimana seharusnya manusia berdosa menempatkan kehendaknya. Karena ketika Kristus menempatkan kehendak natur manusia di dalam Pribadi-Nya tunduk kepada 'pemerintahan Allah,' adalah merupakan suatu contoh bagi kita untuk menekan kekerasan hati, kebodohan dan sikap memberontak terhadap Allah. ${ }^{45}$

Melalui penafsirannya, sebagaimana Dyothelitisme, Calvin mau menyatakan bahwa Pribadi Kristus, melalui kehendak kemanusiaan-Nya selalu tunduk untuk selalu berada di bawah kehendak Allah, hal ini berbeda dengan manusia berdosa yang dengan keras, tanpa pertimbangan, kasar, dan selalu memberontak. Kristus yang dalam Inkarnasi-Nya adalah manusia sejati yang tanpa dosa adalah juga Allah yang sejati. ${ }^{46}$ Bagi Calvin, Kristus yang tanpa dosa tetap memiliki keinginan kemanusiaan-Nya sebagai

42 John Calvin, Commentary to the Colossians in Commentaries on the Epistles of Paul the Apostle to the Philippians, Colossians, and Thessalonians, trans. And ed. by Rev. William Pringle (Baker Books, Grand Rapids, Michigan, 2005), 149.

43 Ibid., 182.

44 Calvin, A Commentary on Harmony of the Evangelists, 3:233.

45 Ibid., 3:233.

46 Calvin, Institutes, 2.13.4. 
manusia yang penuh kelemahan, dan pemikiran ini adalah sesuai dengan pemahaman Dyothelitisme. Pemahaman Dyothelitisme dalam Kristologi Calvin juga nampak pada pemikirannya bahwa Kristus sungguh-sungguh mengalami kesedihan dan penderitaan, merupakan bukti bahwa roh manusia dan tubuh natur manusia-Nya berbagian di dalam penghukuman, supaya kita dapat mengalami penebusan. Kesedihan dan penderitaan yang bukan akibat dosa, melainkan berdasarkan kerelaan-Nya untuk menanggungnya bagi kita. ${ }^{47}$ Perbedaannya adalah bahwa bagi Calvin, natur manusia yang diasumsi Kristus bukanlah 'fallen nature' sebagaimana dipahami Dyothelitisme. ${ }^{48}$ Pribadi Kristus dalam kehendak kemanusiaan-Nya memberikan ketaatan kepada Allah dari posisi kelemahan kemanusiaan-Nya, sehingga Ia dapat dan pantas menjadi contoh ketaatan bagi setiap orang percaya, sebagaimana dinyatakan Törönen:

Having established that will is a natural property both of divine and of human natures, Maximus argues that although Christ has two wills, it does not follow that Christ has two contradicting wills. He makes a distinction between the natural and the gnomic will; the former is characteristic of nature, the latter of person. ${ }^{49}$

Penderitaan Kristus di taman Getsemani menunjukkan kehendak kemanusiaan-Nya. Sebagai seorang manusia yang memohon kepada Allah Bapa agar cawan tersebut berlalu daripada-Nya, menunjukkan Kristus sungguh-sungguh manusia sejati yang taat kepada kehendak Bapa untuk naik ke atas salib, dan sungguh-sungguh menanggung penderitaan dengan rela sampai mati. Calvin menekankan pentingnya pengertian tentang penderitaan Kristus di taman Getsemani bagi pekerjaan penebusan: "Yet here is our wisdom: duly to feel how much our salvation cost the Son of God. "50 Calvin menafsirkan bahwa Kristus turun ke dalam neraka melalui sengsara-Nya di atas kayu salib. ${ }^{51}$ Penafsiran terhadap narasi Getsemani terkait dengan peran Kristus sebagai Mediator, dimana Allah menanggungkan seluruh dosa dan kelemahan kita kepada Pribadi-Nya, dan Kristus menggenapkan peran tersebut melalui kemenangan-Nya berdasarkan ketaatan PribadiNya. Kristus tidak takut terhadap kematian, tetapi kepada murka Allah yang dinyatakan terhadap Pribadi-Nya, dimana Ia berdiri untuk diadili di

47 Ibid., 2.16.12.

48 John Calvin, Commentary on the Holy Gospel of Jesus Christ According to John, vol. third, by Rev. William Pringle (Baker Books, Grand Rapids, Michigan, 2005), 45.

49 Törönen, Union and Distinction, 113.

50 Calvin, Institutes, 2.16.2.

51 Thomas H. McCall, Forsaken: The Trinity and the Cross, and Why it Matters (Inter Varsity Press, Downer Grove, Illinois, 2012), 28-29. 
hadapan Bapa oleh karena dosa-dosa dunia. ${ }^{52}$ Mengenai peran Mediatorial Kristus, Calvin melalui penafsirannya atas Ibrani 4:15, mengatakan:

since Christ of his own accord extends his hand to us, that we have no reason to dread the majesty of Christ since he is our brother, and that there is no cause to fear, lest he, as one unacquainted with evils, should not be touched by any feelings of humanity, so as to bring us help, since he took upon him our infirmities, in order that he might be more inclined to succor us. ${ }^{53}$

Menurut Calvin, di dalam perannya sebagai Mediator, Kristus tidak menempatkan keagungan dan kekudusan-Nya sebagai batasan untuk mengambil kelemahan kita di dalam peran-Nya sebagai Penebus.

Maka di dalam logika Dyothelite Calvin, pengertian tentang pribadi, natur, dan kehendak Kristus merupakan dasar bagi pemahaman doktrinal yang benar. Calvin berpandangan konkretis di dalam memahami natur manusia dalam inkarnasi Kristus, sebagaimana dipahami oleh Maximus:

that Christ, because he was conceived by a spiritual power, is called the holy seed. For, as it was necessary that he should be a real man, in order that he might expiate our sins, and vanquish death and Satan in our flesh; so was it necessary, in order to his cleansing others, that he should be free from every spot and blemish, (1 Peter 1:19. $)^{54}$

Dalam Dyothelitisme, asumsi Sang Logos terhadap natur manusia konkret Yesus dari Nazaret merupakan dasar bagi tergenapinya karya keselamatan yang menyelamatkan tubuh dan jiwa secara utuh. Kerancuan memahami hal tersebut akan membawa bukan saja kepada kesalahan, tetapi juga kepada kebingungan terhadap realita penebusan. Jika Kristus hanya memiliki satu kehendak, yaitu kehendak Ilahi, maka kehendak manusia bukan merupakan bagian yang ditebus oleh Kristus, sehingga apa yang telah Kristus kerjakan dalam inkarnasi-Nya tidak menghasilkan kebebasan sempurna di dalam diri-Nya. Karena manusia akan tetap terbelenggu oleh kehendak keberdosaannya tanpa memiliki harapan. Sehingga proses pengudusan tidak mungkin dapat terjadi sebagaimana aksioma Gregory Nazianzus, bahwa apa yang tidak diasumsi Kristus dalam InkarnasiNya, tidak mengalami penebusan. Bagaimana mungkin kita mengalami penebusan sempurna, jikalau kemanusiaan kita tidak ditebus sempurna. Penebusan harus terjadi bukan hanya terhadap tubuh, tetapi juga terhadap roh, yang mencakup pikiran, kehendak dan afeksi. Kesamaan pemahaman terhadap Dyothelitisme dari Maximus dan Calvin, akan memperkuat dan

52 Calvin, A Commentary on A Harmony of the Evangelists, 3:234.

53 John Calvin, The Commentaries on the Epistle of Paul the Apostle to the Hebrews, trans. William Pringle, Calvin's Commentaries (Baker Books, Grand Rapids, 2003), 93.

54 Calvin, A Commentary on A Harmony of the Evangelists, 1:43. 
memperkaya pemahaman teologis, terutama yang berkatian dengan pribadi dan karya keselamatan Kristus. Penderitaan Kristus di taman Getsemani menunjukkan kehendak ke-manusiaan-Nya. Sebagai seorang manusia yang memohon kepada Allah Bapa agar cawan tersebut berlalu daripada-Nya, menunjukkan Kristus sungguh-sungguh manusia sejati dan sungguh-sungguh menanggung penderitaan dengan rela dan tanpa dosa. Terjadinya kehendak Bapa melalui diri Kristus harus terjadi lewat kehendak kemanusiaan Kristus. Karena di dalam esensi yang sama kehendak ilahi Kristus adalah sama dengan kehendak Bapa dan Roh Kudus.

Doa Kristus di Getsemani sebagaimana dicatat Matius, merupakan bukti ketaatan natur manusia di dalam Pribadi Kristus kepada kehendak Bapa, agar yang terjadi adalah kehendak Bapa dan bukan kehendak natur manusia, ketaatan tersebut merupakan bentuk penyangkalan diri. Maka hal tersebut merupakan pola ketaatan dalam bentuk penyangkalan diri yang harus diikuti oleh setiap orang percaya. Cooper menghubungkan pola ketaatan dan penyangkalan diri tersebut melalui apa yang dituliskan rasul Paulus bagi jemaat di Galatia 2:20a, dan lebih jauh ia menyatakan bahwa:

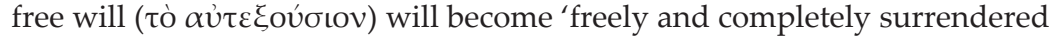
to God, submitting to a state of being ruled by refraining from that which wills anything contrary to what God wills'.55

Berdasarkan kehendak bebas natur kemanusiaan-Nya, maka apa yang Kristus nyatakan di dalam doa Getsemani adalah untuk menyatakan ketaatan-Nya dan bukan sebagai bentuk penolakan atau perbedaan kehendak antara Pribadi Kristus dengan Bapa. Sebagaimana dinyatakan oleh Bathrellos, tujuannya adalah agar kita lebih memihak kepada kehendak Bapa daripada kehendak diri; 'because Christ wanted to teach us to prefer the will of God to our own will. ${ }^{156}$ Kebebasan kehendak natur manusia Kristus justru dipakai untuk sepenuhnya menaati kehendak Bapa. Apa yang terjadi di dalam taman Gestemani, melalui doa-Nya, maka kita dapat mengerti bahwa permohonan-Nya kepada Bapa adalah bentuk kehendak bebas dari natur manusia-Nya, untuk menyatakan apa yang kita inginkan yaitu kehidupan, dan juga apa yang tidak kita inginkan yaitu kematian. ${ }^{57}$ Tetapi Pribadi Kristus menempatkan kehendak bebas natur manusia tersebut di bawah ketaatan-Nya secara total kepada kehendak Bapa, yaitu bagi terlaksananya karya penebusan dengan sempurna.

\footnotetext{
55 Cooper, The Body in St. Maximus the Confessor, 90.

56 Bathrellos, The Byzantine Christ, 77.

57 lbid., 83.
} 


\section{Kesimpulan}

Maka kesesuaian pemahaman terhadap doktrin dua-kehendak (Dyothelite) Kristus antara Maximus dan Calvin, merupakan hal yang teramat penting bagi keutuhan kebenaran pemahaman Doktrin Keselamatan yang menyelamatkan tubuh dan jiwa manusia secara sempurna. Sebagaimana aksioma Gregory Nazianzus, bahwa yang mengalami penebusan adalah apa yang diasumsi oleh Sang Anak Allah di dalam Inkarnasi-Nya, yaitu tubuh dan roh/jiwa sebagai satu kesatuan di dalam pribadi manusia. Pemahaman Calvin terhadap Kristologi Dyothelite melalui pemikiran dan penafsiran terhadap peran Pribadi Kristus sebagai Mediator, serta kesamaan pemahamannya terhadap terminologi abad ke-empat mengenai pribadi dan natur. Kristus sebagai Sang Mediator adalah mewakili Allah dan manusia. Di dalam Pribadi dan melalui kedua natur-Nya, Kristus melaksanakan dengan sempurna peran-Nya sebagai Sang Mediator. Karya-karya Calvin juga menyatakan bahwa Sang Logos mengasumsi natur manusia konkret bagi pelaksanaan dan penggenapan sempurna karya penebusan melalui kedua natur-Nya. Hal ini membuktikan bahwa pemahaman mengenai Inkarnasi Kistus di dalam teologi Reformed sebagaimana diwakili oleh Calvin adalah sesuai dengan Dyothelitisme yang telah diterima sebagai pemahaman ortodoks Gereja. 